\section{$\beta$ globin mutations in Turkish, Northern Iraqi and Albanian patients with $\beta$ thalassemia major}

\author{
Veysel Sabri Hancer, ${ }^{1}$ Tunc Fisgin, ${ }^{2}$ \\ Murat Buyukdogan, ${ }^{3}$ Ceyhun Bozkurt, ${ }^{4}$ \\ Sotiraq Lako ${ }^{5}$ \\ ${ }^{1}$ Department of Medical Genetics, \\ Faculty of Medicine, Istinye University, \\ Istanbul, Turkey; ${ }^{2}$ Department of Child \\ Health and Diseases, Faculty of \\ Medicine, Bahcesehir University, \\ Istanbul, Turkey; ${ }^{3}$ Department of \\ Medical Genetics, Faculty of Medicine, \\ Istinye University, Istanbul, Turkey; \\ ${ }^{4}$ Department of Child Health and \\ Diseases, Faculty of Medicine, Istinye \\ University, Istanbul, Turkey; \\ ${ }^{5}$ Hematology Clinic, American Hospital, \\ Tirana, Albania
}

\begin{abstract}
The mutation detection of $\beta$ thalassemia is absolutely necessary for molecular diagnosis, as well as any genetic epidemiological study. The $\beta$ globin gene has 3 exons and 2 introns, involved in $\beta$-thalassemic pathogenesis. The study aim of the study is to characterize the spectrum of $\beta$ globin gene mutations in 136 Turkish, Northern Iraqi and Albanian pediatric $\beta$ thalassemia major patients. After genomic DNA extraction from venous blood and amplification of the target DNA regions with PCR, genotyping was achieved by Sanger based DNA sequencing. The IVSI-110 G>A mutation was the most frequent allele in the Turkish and Albanian patients. In Northern Iraqi patients IVSI-1 G>A was is the most frequent. There are two mutations are firstly reported for Albania [c.*111 A>G 3' UTR (rs63751128) and c.113 G>A (p.Trp38Ter, p.W38*) (rs35887507)] with this study. These findings may be of value for genetic counseling, premarital diagnosis, prenatal diagnosis and prevention programs.
\end{abstract}

\section{Introduction}

$\beta$ thalassemia is the most common autosomal recessive single gene disorder in the world. ${ }^{1}$ According to the World Health Organization, abnormal hemoglobin frequency is at $7 \%$ globally. ${ }^{2}$ The $\beta$ thalassemias are is a group of hereditary disorders with autosomal recessive inheritance characterized by the presence of defective synthesis of the $\beta$ globin chain, an integral component of the hemoglobin molecule, resulting in either partial synthesis $(\beta+)$ or complete absence $(\beta 0))^{3,4}$ Patients with $\beta$ thalassemia require life-long blood transfusions to ensure an adequate hemoglobin $\mathrm{Hb}$ ) level and iron chelation therapy ensure enough hemoglobin $(\mathrm{Hb})$ level to prevent iron accumulation of iron. Approximately $800 \beta$-globin gene mutations different mutations of the $\beta$-globin gene (HBB, MIM\#141900; GenBank genomic reference sequence NG_000007.3) have been documented in the HbVar database (http://globin.bx.psu.edu/hbvar). Regional differences in the frequency of various mutations may offer clues regarding migration patterns and the ethnic background of a particular population. ${ }^{5}$ Clinical manifestations are diverse and range from asymptomatic hypochromia and microcytosis to profound anemia leading to death in early childhood if untreated. Individuals who are homozygous for the HBB genes have severe, transfusion-dependent anemia and are said to have $\beta$-thalassemia major. $\beta$-thalassemia intermedia is a condition in which the degree of hemolysis is milder although the patient may have a deficiency of both $\beta$ genes. ${ }^{3-5}$ Therefore, thalassemia intermedia is essentially a descriptive term that refers to minimal or no need for transfusions. The presence of one normal gene in the heterozygotes usually leads to enough normal $\beta$-globin chain synthesis so that the affected individuals are usually asymptomatic with only a hypochromic and microcytic red blood cells. This condition is referred to as $\beta$ thalassemia minor. The general rate of carriers for $\beta$ thalassemia is $2 \%$ in Turkey, but in some provinces of Turkey, it is $9-10 \%$. The aim of this study is to characterize the spectrum of $\beta$ globin mutations in Turkish, Northern Iraqi and Albanian pediatric $\beta$ thalassemia major patients. ${ }^{6-14}$

\section{Materials and Methods}

Our inclusion criteria were that patients should have had a diagnosis of $\beta$ thalassemia and live in the country they were in. $\beta$ Thalassemia major was diagnosed based on transfusion- dependent hypochromic and microcytic anemia starting from childhood, and $\mathrm{Hb}$ electrophoresis in 66 Turkish, 46 Northern Iraqi and 24 Albanian patients. Patients were transfusion dependent with typical hematological picture. Written informed consent from the patients and local ethics committee approval was obtained taken. Peripheral blood samples were collected in EDTAcontaining tubes of the patients diagnosed
Correspondence: Veysel Sabri Hancer, Professor, Department of Medical Genetics, Faculty of Medicine, Istinye University, Istanbul, Turkey.

Tel.: +90.5336343014.

E-mail: vshancer@yahoo.com

Key words: $\beta$ globin mutations; thalassemia major; Turkey; Northern Iraq; Albania.

Contributions: VSH, conceived and planned the experiments, writing of the manuscript; $\mathrm{TF}$, planned the experiments and the writing of the manuscript; $\mathrm{MB}$, analysis of the results; $\mathrm{CB}$, drafted the manuscript and designed the figures; SL, writing of the manuscript.

Conflict of interest: the authors declare no conflicts of interest.

Received for publication: 10 January 2018 .

Revision received: 23 March 2018.

Accepted for publication: 24 April 2018.

This work is licensed under a Creative Commons Attribution 4.0 License (by-nc 4.0).

(C) Copyright V.S. Hancer et al., 2018

Licensee PAGEPress, Italy

Thalassemia Reports 2018; 8:7286

doi:10.4081/thal.2018.7286

with $\beta$ Thalassemia by hemoglobin electrophoresis and complete blood counts at 6 different hospitals (4 in Turkey, 1 Northern Iraq and 1 in Albania) came to our center for genetic analysis between 2016-2018 Genomic DNA was extracted from white blood cells using a commercial kit (Anatolia, 102-DNA isolation kit, Turkey). gDNA samples stored at $4^{\circ} \mathrm{C}$ till the PCR amplification. $\mathrm{HBB}$ gene was amplified as 2 polymerase chain reaction (PCR) fragments (from the -101 position to the Poly-A signal) using 30-50 ng of genomic DNA in 25$\mu \mathrm{L}$ reaction volumes. The PCR mixture contained $12.5 \mu \mathrm{L}$ of $2 \mathrm{X}$ PCR master mix and 5 pmol of each primer (GML, Wollerau, Switzerland). The amplification conditions were as following: $94^{\circ} \mathrm{C}$ for $1 \mathrm{~min} ; 65^{\circ} \mathrm{C}$ for $1 \mathrm{~min} ; 72^{\circ} \mathrm{C}$ for $1 \mathrm{~min}$. Thirty-six There were a total of 36 cycles were conducted. The final extension period lasted for $3 \mathrm{~min}$. Excess primers and unincorporated dNTPs in each PCR products were cleaned by Exosap IT (USB Corporation, USA). The sequencing was performed using the BigDye Terminator v3.1 Cycle Sequencing Kit. The sequencing amplicons were purified with a DNA sequencing clean up kit (Zymo Research, USA). Purified amplicons were analysed with ABI Prism 3700xl Genetic Analyzer (Applied Biosystems, Foster City, CA, USA). 
reported for Albania (9) and with this study that are not in Turkish or Northern Iraqi patients as shown in Figures 1 and 2, respectively.

The major study limitation of this study was lack of the genotype-phenotype comparisons due to deficient clinical data such as iron accumulation, number with of splenectomy, transfusion frequency etc. Thalassemia can be controlled cost effectively by carrier detection and genetic counseling programs in countries where the disease occurrence of the disease is frequent.
First Population screening was has been started in 1993 in Turkey and a national prevention program, which is including carrier screening, genetic counseling, prenatal diagnosis, education, pre-implantation genetic treatment was has been started in 2003. According to reports by The Turkish Ministry of Health reports the number of infants born with thalassemia was decreased by $87 \%$ in $2008 .{ }^{21}$ In conclusion, we describe the spectrum of mutations among 136 patients with $\beta$ thalassemia major from Turkey, Northern Iraq and tively. As shown in Table 2, The IVSI-110 $\mathrm{G}>\mathrm{A}$ mutation was the most frequent allele in the Turkish and Albanian patients with $\beta$ Thalassemia major (Table 2). In Northern Iraqi patients IVSI- $1 \mathrm{G}>\mathrm{A}$ is the most frequent.

\section{Discussion and Conclusions}

$\beta$ Thalassemia is the most common monogenic autosomal ressesive disorder in the regions where malaria was until recently or is currently endemic. Migration flows are an influence on the spread of the disease. In addition, consanguineous marriages contribute are also contributed to the spread. Both The frequency of $\beta$ thalassemia major and mutation type rate differs according to geographical region. In this study, we examine $136 \beta$ thalassemia major patients from Turkey, Northern Iraq and Albania. Our results indicate that Turkish mutation frequencies are similar with Albanian but different from Northern Iraq. Turkey is like a bridge between Asia and Europe. Throughout Turkey's the history, the existence of various ethnicities, wars and migrations are responsible for $\beta$ Thalassemia mutation heterogeneity of $\beta$ Thalassemia. As we expected, the mutation frequencies are different between countries east or west of Turkey and those wests of. The spectrum of $\beta$ thalassemia major mutations detected in our study is in accordance with several studies. IVSI-110 $\mathrm{G}>\mathrm{A}$ mutation is the most common in patients from Turkey, Macedonia, Greece, Bulgaria, Albania, Romania, Azerbaijan (6-14). c.118 C>T $(\mathrm{CD} 39 \mathrm{C}>\mathrm{T})$ is the most common in Italy, France and Spain. ${ }^{15-17}$ For The thalassemia major data about the most common mutation types data from the Iraqi Kurdish region, data about the most common mutation types are compatible with this study. ${ }^{18-}$ ${ }^{20} \mathrm{HBB}$ common mutation types and rates in Albanian and Turkish thalassemia major patients were found very similar. Pathogenic c.*111 A>G 3' UTR (rs63751128) and c.113 G>A (p.Trp38Ter, pW38*) (rs35887507) mutations are firstly

\begin{tabular}{lccc} 
& Turkish & Northern Iraqi & Albanian \\
Patient number & 66 & 46 & 24 \\
Gender: male/female (\%) & $35 / 31(53 / 47)$ & $20 / 26(43.5 / 56.5)$ & $10 / 14(41.7 / 58.3)$ \\
\hline Age range (years) & $1-17$ & $1-15$ & $2-15$ \\
Mean age (years) & 8.4 & 7.5 & 7.6 \\
\hline Homozygous & 46 & 26 & 6 \\
Heterozygous & 20 & 20 & 18 \\
\hline
\end{tabular}

\begin{tabular}{lccc} 
& Turkish & Northern Iraqi & Albanian \\
Patient number & 66 & 46 & 24 \\
Gender: male/female (\%) & $35 / 31(53 / 47)$ & $20 / 26(43.5 / 56.5)$ & $10 / 14(41.7 / 58.3)$ \\
\hline Age range (years) & $1-17$ & $1-15$ & $2-15$ \\
Mean age (years) & 8.4 & 7.5 & 7.6 \\
\hline Homozygous & 46 & 26 & 6 \\
Heterozygous & 20 & 20 & 18 \\
\hline
\end{tabular}

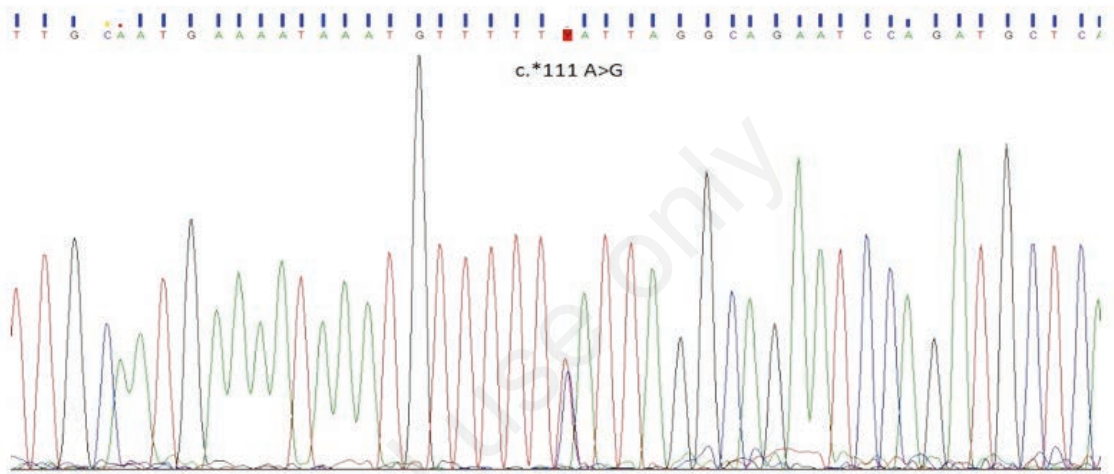

Figure 1. Electropherogram result of the $c^{*} 111 \mathrm{~A}>\mathrm{G}$ mutation.

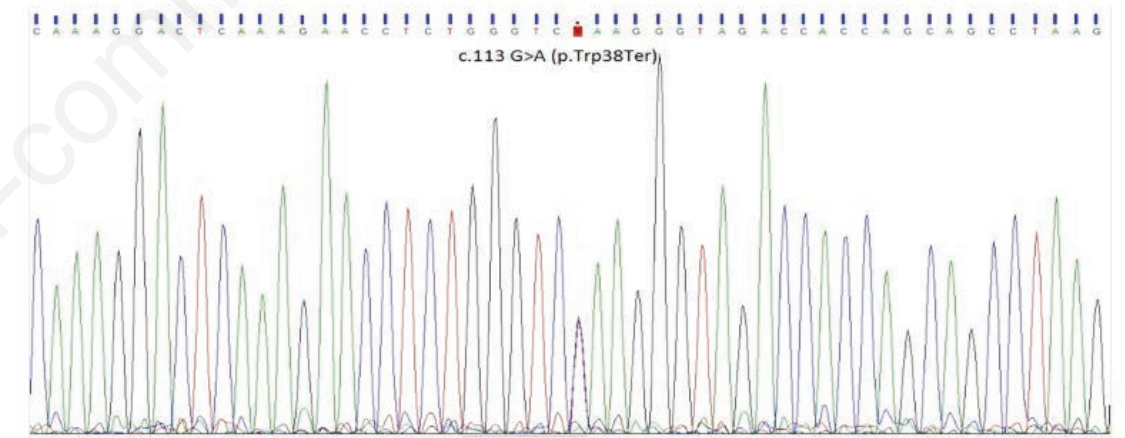

Figure 2. Electropherogram result of the c.113 G>A mutation

Table 1. Patient characteristics. 
Table 2. Distribution of detected mutations.

\begin{tabular}{|c|c|c|c|c|c|c|c|}
\hline Mutation Name & Type & $\begin{array}{c}\text { Turkish } \\
n=66\end{array}$ & $\%$ & $\begin{array}{c}\text { Northern Iraqi } \\
n=46\end{array}$ & $\%$ & $\begin{array}{c}\text { Albanian } \\
\mathrm{n}=24\end{array}$ & $\%$ \\
\hline c. $93-21 \mathrm{G}>\mathrm{A}($ IVSI-110 G>A) & $\begin{array}{l}\text { Homozygous } \\
\text { Compound }\end{array}$ & $\begin{array}{c}14 \\
6\end{array}$ & 25.76 & $\begin{array}{l}2 \\
0\end{array}$ & 4.17 & $\begin{array}{c}3 \\
7.6\end{array}$ & $\begin{array}{c}25 \\
27.08\end{array}$ \\
\hline c.25_26delAA (Cd8 delAA) & $\begin{array}{l}\text { Homozygous } \\
\text { Compound }\end{array}$ & $\begin{array}{l}4 \\
2\end{array}$ & 7.57 & $\begin{array}{l}2 \\
8\end{array}$ & 12.5 & $\begin{array}{l}0 \\
0\end{array}$ & 0 \\
\hline c. $92+6 \mathrm{~T}>\mathrm{C}($ IVSI-6 T>C) & $\begin{array}{l}\text { Homozygous } \\
\text { Compound }\end{array}$ & $\begin{array}{l}4 \\
6\end{array}$ & 10.6 & $\begin{array}{l}0 \\
4\end{array}$ & 4.17 & $\begin{array}{c}1 \\
10\end{array}$ & 25 \\
\hline c. $92+1 \mathrm{G}>\mathrm{A}($ IVSI-1 G>A) & $\begin{array}{l}\text { Homozygous } \\
\text { Compound }\end{array}$ & $\begin{array}{l}6 \\
4\end{array}$ & 12.12 & $\begin{array}{c}6 \\
10\end{array}$ & 22.92 & $\begin{array}{l}1 \\
2\end{array}$ & 8.33 \\
\hline c.17_18delCT [Cd5(-CT] & $\begin{array}{l}\text { Homozygous } \\
\text { Compound }\end{array}$ & $\begin{array}{l}2 \\
4\end{array}$ & 6.06 & $\begin{array}{l}2 \\
0\end{array}$ & 4.17 & $\begin{array}{l}0 \\
2\end{array}$ & 4.17 \\
\hline c. $-30 \mathrm{~T}>\mathrm{A}(\mathrm{CAP}+21 \mathrm{~T}>\mathrm{A})$ & $\begin{array}{l}\text { Homozygous } \\
\text { Compound }\end{array}$ & $\begin{array}{l}4 \\
2\end{array}$ & 7.57 & $\begin{array}{l}0 \\
0\end{array}$ & 0 & $\begin{array}{l}0 \\
0\end{array}$ & 0 \\
\hline c.118 C>T (CD39 CAG>TAG) & $\begin{array}{l}\text { Homozygous } \\
\text { Compound }\end{array}$ & $\begin{array}{l}6 \\
0\end{array}$ & 9.09 & $\begin{array}{l}0 \\
0\end{array}$ & 0 & $\begin{array}{l}1 \\
7\end{array}$ & 18.75 \\
\hline c. $20 \mathrm{~A}>\mathrm{T}(\mathrm{Cd} 6 \mathrm{GAG}>\mathrm{GTG})$ & $\begin{array}{l}\text { Homozygous } \\
\text { Compound }\end{array}$ & $\begin{array}{l}0 \\
2\end{array}$ & 1.51 & $\begin{array}{l}4 \\
0\end{array}$ & 8.33 & $\begin{array}{l}0 \\
1\end{array}$ & 2.08 \\
\hline c. $-31 \mathrm{C}>\mathrm{T}(\mathrm{CAP}+20 \mathrm{C}>\mathrm{T})$ & $\begin{array}{l}\text { Homozygous } \\
\text { Compound }\end{array}$ & $\begin{array}{l}2 \\
6\end{array}$ & 7.57 & $\begin{array}{l}0 \\
0\end{array}$ & 0 & $\begin{array}{l}0 \\
2\end{array}$ & 4.17 \\
\hline c.316-106 C>G (IVSII-745 C>G) & $\begin{array}{l}\text { Homozygous } \\
\text { Compound }\end{array}$ & $\begin{array}{l}0 \\
6\end{array}$ & 4.54 & $\begin{array}{l}0 \\
0\end{array}$ & 0 & $\begin{array}{l}0 \\
1\end{array}$ & 2.08 \\
\hline c. $315+1 \mathrm{G}>\mathrm{A}($ IVSII-1 G>A) & $\begin{array}{l}\text { Homozygous } \\
\text { Compound }\end{array}$ & $\begin{array}{l}0 \\
0\end{array}$ & 0 & $\begin{array}{l}4 \\
6\end{array}$ & 14.58 & $\begin{array}{l}0 \\
1\end{array}$ & 2.08 \\
\hline c.27_28 insG (CD8/9+G) & $\begin{array}{l}\text { Homozygous } \\
\text { Compound }\end{array}$ & $\begin{array}{l}0 \\
0\end{array}$ & 0 & $\begin{array}{l}0 \\
2\end{array}$ & 2.08 & $\begin{array}{l}0 \\
0\end{array}$ & 0 \\
\hline c. $92+5$ G>C (IVSI-5 G>C) & $\begin{array}{l}\text { Homozygous } \\
\text { Compound }\end{array}$ & $\begin{array}{l}0 \\
0\end{array}$ & 0 & $\begin{array}{l}0 \\
4\end{array}$ & 4.17 & $\begin{array}{l}0 \\
0\end{array}$ & 0 \\
\hline c.135delC (CD44-C) & $\begin{array}{l}\text { Homozygous } \\
\text { Compound }\end{array}$ & $\begin{array}{l}2 \\
0\end{array}$ & 3.03 & $\begin{array}{l}4 \\
2\end{array}$ & 10.42 & $\begin{array}{l}0 \\
1\end{array}$ & 2.08 \\
\hline c.68_74del7 (CD22-24 delAAGTTGG) & $\begin{array}{l}\text { Homozygous } \\
\text { Compound }\end{array}$ & $\begin{array}{l}0 \\
0\end{array}$ & 0 & $\begin{array}{l}0 \\
4\end{array}$ & 4.17 & $\begin{array}{l}0 \\
0\end{array}$ & 0 \\
\hline c. $-50 \mathrm{~A}>\mathrm{C}(\mathrm{CAP}+1 \mathrm{~A}>\mathrm{C})$ & $\begin{array}{l}\text { Homozygous } \\
\text { Compound }\end{array}$ & $\begin{array}{l}0 \\
0\end{array}$ & 0 & $\begin{array}{l}0 \\
2\end{array}$ & 2.08 & $\begin{array}{l}0 \\
0\end{array}$ & 0 \\
\hline c. $47 \mathrm{G}>\mathrm{A}(\mathrm{CD} 15 \mathrm{TGG}>\mathrm{TAG})$ & $\begin{array}{l}\text { Homozygous } \\
\text { Compound }\end{array}$ & $\begin{array}{l}0 \\
0\end{array}$ & 0 & $\begin{array}{l}2 \\
0\end{array}$ & 4.17 & $\begin{array}{l}0 \\
0\end{array}$ & 0 \\
\hline c. $364 \mathrm{G}>\mathrm{C}(\mathrm{CD} 121 \mathrm{GAA}>\mathrm{CAA})$ & $\begin{array}{l}\text { Homozygous } \\
\text { Compound }\end{array}$ & $\begin{array}{l}2 \\
0\end{array}$ & 3.03 & $\begin{array}{l}0 \\
0\end{array}$ & 0 & $\begin{array}{l}0 \\
0\end{array}$ & 0 \\
\hline c.93-3 T>G (IVSI-128 T>G) & $\begin{array}{l}\text { Homozygous } \\
\text { Compound }\end{array}$ & $\begin{array}{l}0 \\
0\end{array}$ & 0 & $\begin{array}{l}0 \\
2\end{array}$ & 2.08 & $\begin{array}{l}0 \\
0\end{array}$ & 0 \\
\hline c.316-3 C>A (IVSII-848 C>A) & $\begin{array}{l}\text { Homozygous } \\
\text { Compound }\end{array}$ & $\begin{array}{l}0 \\
2\end{array}$ & 1.51 & $\begin{array}{l}0 \\
0\end{array}$ & 0 & $\begin{array}{l}0 \\
0\end{array}$ & 0 \\
\hline c.113 G>A (CD37 TGG>TAG) & $\begin{array}{l}\text { Homozygous } \\
\text { Compound }\end{array}$ & $\begin{array}{l}0 \\
0\end{array}$ & 0 & $\begin{array}{l}0 \\
0\end{array}$ & 0 & $\begin{array}{l}0 \\
1\end{array}$ & 2.08 \\
\hline c. ${ }^{*} 111 \mathrm{~A}>\mathrm{G}$ (PolyA AATAA $>$ AATGA & $\begin{array}{l}\text { Homozygous } \\
\text { Compound }\end{array}$ & $\begin{array}{l}0 \\
0\end{array}$ & 0 & $\begin{array}{l}0 \\
0\end{array}$ & 0 & $\begin{array}{l}0 \\
1\end{array}$ & 2.08 \\
\hline
\end{tabular}

Albania. These findings may be of important for genetic counseling, premarital diagnosis, prenatal diagnosis and prevention programs.

Further prospective studies in larger cohorts of patients are needed to confirm the allele frequencies.

These findings will provide a sound foundation on which to base a preventive program for thalassemia, and, also will facilitate the improvement of medical services such as carrier screening, genetic counseling and prenatal diagnosis.

\section{References}

1. Wetherall DJ, Clegg JB. The thalassemia syndromes. 4th ed. Oxford, UK: Blackwell Scientific Publications; 2008.

2. World Health Organization. Management of Haemoglobin Disorders: Report of Joint WHO-TIF Meeting. Geneva, Switzerland: WHO; 2012.

3. Rachmilewitz EA, Giardina PJ. How I treat thalassemia. Blood 2011;118:
3479-88.

4. Galanello R, Origa R. Orphanet J. Betathalassemia. Orphanet J Rare Dis 2010;21:5-11.

5. Aksoy M. Hemoglobinopathies in Turkey. Hemoglobin 1985;9:209-18.

6. Petkov GH, Efremov GD. Molecular basis of beta-thalassemia and other hemoglobinopathies in Bulgaria: an update. Hemoglobin 2007;31:225-32.

7. Atanasovska B, Bozhinovski G, Chakalova L, et al. Molecular diagnostics of $\beta$-thalassemia. Balkan J Med 
Genet 2012;15:61-5.

8. Boussiou M, Karababa P, Sinopoulou $\mathrm{K}$, et al. The molecular heterogeneity of beta-thalassemia in Greece. Blood Cells Mol Dis 2008;40:317-9.

9. Babameto-Laku A, Mitre A, Berisha S, et al. Molecular Genetic characterization of $\beta$ thalassemia and sickle cell syndrome in the Albanian population. Balkan J Med Genet 2011;14:45-50.

10. Tadmouri GA, Basak AN. Beta-thalassemia in Turkey: a review of the clinical, epidemiological, molecular, and evolutionary aspects. Hemoglobin 2001;25:227-39.

11. Talmaci R, Traeger-Synodinos J, Kanavakis E, et al. Scanning of $\beta$-globin gene for identification of $\beta$-thalassemia mutation in Romanian population. J Cell Mol Med 2004;8:232-40.

12. Boletini E, Svobodova M, Divoky V, et al. Sickle cell anemia, sickle cell betathalassemia, and thalassemia major in
Albania: characterization of mutations. Hum Genet 1994;93:182-7.

13. Kuliev AM, Rasulov IM, Dadasheva T, et al. Thalassaemia in Azerbaijan. J Med Genet 1994;31:209-12.

14. Curuk MA, Yuregir GT, Asadov CD, et al. Molecular characterization of betathalassemia in Azerbaijan. Hum Genet 1992;90:417-9.

15. De Sanctis V, Kattamis C, Canatan D, et al. $\beta$-Thalassemia Distribution in the Old World: an Ancient Disease Seen from a Historical Standpoint. Mediterr J Hematol Infect Dis 2017; e2017018.

16. Amselem S, Nunes V, Vidaud M, et al. Determination of the spectrum of betathalassemia genes in Spain by use of dot-blot analysis of amplified beta-globin DNA. Am J Hum Genet 1988;43:95-100.

17. Fernandez E, Bienvenu T, Desclaux Arramond F, et al. Use of chemical clamps in denaturing gradient gel elec- trophoresis: application in the detection of the most frequent Mediterranean beta-thalassemic mutations. PCR Methods Appl 1993;3:122-4.

18. Jalal SD, Al-Allawi NA, Bayat N, et al. $\beta$-Thalassemia mutations in the Kurdish population of northeastern Iraq. Hemoglobin 2010;34:469-76.

19. Shamoon RP, Al-Allawi NA, Cappellini $\mathrm{MD}$, et al. Molecular Basis of $\beta$-thalassemia Intermedia in Erbil Province of Iraqi Kurdistan. Hemoglobin 2015;39:178-83.

20. Rahimi Z, Muniz A, Mozafari H. Abnormal hemoglobins among Kurdish population of Western Iran: hematological and molecular features. Mol Biol Rep 2010;37:51-7.

21. Canatan D, Aydinok Y, Kilinc Y, et al. National thalassemia prevention campaign: the Tolatır Project. Turk J Hematol 2013;30:91-2. 